\title{
THE EFFECT OF ELEPHANT FOOT YAM (Amorphophallus campanulatus) FLOUR AND SOYBEAN OIL ADDITION ON THE PHYSICOCHEMICAL AND SENSORY PROPERTIES OF BEEF SAUSAGE
}

\author{
Eny Sri Widyastuti ${ }^{1)}$, Djalal Rosyidi ${ }^{2),}$, Lilik Eka Radiati ${ }^{2)}$, Purwadi $^{2)}$ \\ 1) Postgraduate Student, Faculty of Animal Science, Universitas Brawijaya, J1. Veteran, Ketawanggede, Kec. \\ Lowokwaru, Kota Malang, Jawa Timur Indonesia 65145 \\ ${ }^{2)}$ Lecturer of Animal Product Department, Faculty of Animal Science, Universitas Brawijaya, Jl. Veteran, \\ Ketawanggede, Kec. Lowokwaru, Kota Malang, Jawa Timur Indonesia 65145 \\ *Email: djalal_tht@ub.ac.id
}

Submitted 6 May 2020; Accepted 11 June 2020

\begin{abstract}
The texture of sausage was affected by its binding agent. Elephant foot yam (Amorphophallus campanulatus) flour was a potential natural binding agent and filler for sausage. The objective of this study was to evaluate the effect of elephant foot yam flour and soybean oil addition to the physicochemical properties and sensory attributes of beef sausage. A randomized block design with two factors and three replications were employed. Three addition levels (10\%, $15 \%$ and $20 \%$ of meat weight) were used for both elephant foot yam flour and soybean oil. The results showed that the addition of elephant foot yam flour significantly $(\mathrm{P} \leq 0.01)$ affect the water-holding capacity $(\mathrm{WHC})$ and sausage texture. The effect $(\mathrm{P} \leq 0.05)$ was also observed on the redness color ( $\mathrm{a}^{*}$ value). However, no effect was found on $\mathrm{pH}, \mathrm{L}$ and $\mathrm{b}^{*}$ values. On the other hand, the WHC and sausage texture were also significantly $(\mathrm{P} \leq 0.05)$ affected by soybean oil addition without altering $\mathrm{pH}$ and color. The highest addition level (20\%) for both elephant foot yam flour and soybean oil showed a firm and compact beef sausage micro-structure with small pores. The highest fat and crude fiber content were also found in this group (20\% addition level) and the sensory attributes (texture, aroma and taste) of the former group were comparable with the group with lowest addition level (10\%). Therefore, elephant foot yam flour can be used as filler for producing both reduced-fat and typical beef sausage.
\end{abstract}

Keywords: Emulsified sausage; filler; gelling properties; technological properties 


\section{INTRODUCTION}

Sausage is a meat-based food product made from ground beef mixed with filling and binding agents as well as other seasonings then placed into sausage casing. Basically, the sausage production is a simple process, involving the controlled structural and chemical changes of meat determined by the used ingredients (Essien, 2003). Non meat ingredients such as starch, protein isolate and dietary fiber, are commonly added in order to improve the quality as well as production cost (Abdolghafour and Saghir, 2014). It is considering that those compounds would have water binding properties, thus affect the sausage texture, emulsion stability, color, cooking loss, and flavor (Prastini and Widjanarko, 2015). Fat is also commonly added to the sausage mixture to make up for the fat loss during cooking, decrease the cell wall breakdown, and to improve the sausage flavor (Essien, 2003). The added fat could be both in a solid (beef or pork fat) or liquid (natural oil) form. One of the potential fat sourced ingredients to be added to the sausage is soybean oil, as it has better fatty acid content compared to most solid fat, has zero cholesterol, rich of unsaturated fat (linolenic and linoleic acid), and antioxidants (Isa, 2011).

Elephant foot yam flour is made from elephant foot yam bulb which had $68.21 \%$ starch (28.98 amylose), $13.71 \%$ dietary fiber $(8.44 \%$ dissolved and $5.27 \%$ undissolved fiber), and in vitro digestibility at $61.75 \%$ (Faridah, 2005). The high starch and dietary fiber content in elephant foot yam flour showed its potential to be used as binding agent in meat processing, as both compounds had the ability to bind water and form gel. Elephant foot yam is in the family of porang (Amorphophallus muwlleri

*Corresponding author:

Djalal Rosyidi

Email: djalal_tht@ub.ac.id

Faculty of Animal Science, Universitas Brawijaya, Jl. Veteran, Ketawanggede, Kec. Lowokwaru, Kota Malang, Jawa Timur Indonesia 65145
Blume) that contained high dissolved dietary fiber known as glucomannan, which reached $64.98 \%$ (Prastini and Widjanarko, 2015). Faridah (2005) added that elephant foot yam flour had low glycemic index (42) and showed a promising potential to be utilized as functional food for human health. In this study, we evaluate the effect of elephant foot yam flour and soybean oil addition on the physicochemical and sensory properties of beef sausage.

\section{MATERIALS AND METHODS}

\section{Elephant foot yam flour and beef sausage production}

The meat used in this research is the round part of beef meat from local market in Malang, Indonesia. The beef meat was trimmed from subcutaneous fat. The elephant foot yam flour was produced from elephant foot yam bulb by following Faridah (2005). The bulb was peeled, cut and washed and then soaked in $3 \%$ salt water. The bulb was then heated at $50^{\circ} \mathrm{C}$ on the oven for $12 \mathrm{~h}$, grinded and sifted with 100 mesh screens.

The produced elephant foot yam flour had $9.49 \%$ moisture, $7.02 \%$ protein, $0.62 \%$ fat, $10.85 \%$ ash, $71.98 \%$ carbohydrate, $4.22 \%$ crude fiber, $68.21 \%$ starch, and $26.87 \%$ dietary fiber. The soybean oil used in this study contained $8 \%$ saturated fat, $13.33 \%$ unsaturated fat, and $32 \%$ double bond unsaturated fat for each $2000 \mathrm{kcal}$. The research was conducted in a randomized block design with two factorials to understand the optimum elephant yam flour and soybean oil addition. The first factor is the elephant foot yam flour additions ( $\mathrm{S} 1=$ $10 \% ; \mathrm{S} 2=15 \%$; and $\mathrm{S} 3=20 \%$ ), and the $\mathrm{s}$ factor is the soybean oil additions ( $\mathrm{L} 1=$ $10 \%$; $\mathrm{L} 2=15 \%$; and $\mathrm{L} 3=20 \%$ ) based on

How to cite:

Widyastuti, E. S., Rosyidi, D., Radiati, L. E., \& Purwadi. (2020). The Effect of Elephant Foot Yam (Amorphophallus campanulatus) Flour and Soybean Oil Addition on the Physicochemical and Sensory Properties of Beef Sausage. Jurnal Ilmu dan Teknologi Hasil Ternak, 15 (2), 119-130 
the beef weight, respectively. Other used ingredients were $20 \mathrm{~g}$ salt, $15 \mathrm{~g}$ sucrose, $15 \mathrm{~g}$ seasoning, $60 \mathrm{~g}$ yolk and $300 \mathrm{~g}$ ice for $1 \mathrm{~kg}$ of beef meat. The beef meat was grinded in the meat grinder, and then mixed with other ingredients in the chopper, except for the elephant foot yam flour which was added little by little and then followed with soybean oil addition. The sausage mixture was then placed in the polyamide plastic sausage casing with the diameter at $16.86 \mathrm{~mm}$ by using hydraulic sausage filling machine, then boiled at $80^{\circ} \mathrm{C}$ for $20 \mathrm{~min}$, placed in a $5^{\circ} \mathrm{C}$ ice cold water for $10 \mathrm{~min}$, and drained before analyzed.

\section{pH}

As much as $5 \mathrm{~g}$ of beef sausage was placed on $50 \mathrm{~mL}$ Erlenmeyer flask, added with $20 \mathrm{~mL}$ distilled water, and then homogenized. The $\mathrm{pH}$ was then measured to the solution by using $\mathrm{pH}$ meter. The measurement was done for 2 times for each sample.

\section{Color}

The color measurement was done on the inner part of the sausage by using Color Reader (Minolta). The illuminant $\mathrm{C}$ was used to detect brigtness, and $\mathrm{BaCl}_{2}$ was used as the standard. The color data were presented in stimulus coordinate system (CIE Lab color scale) to measure the $\mathrm{L}, \mathrm{a}^{*}$, and $\mathrm{b}^{*}$ color.

\section{Water-holding capacity (WHC)}

The water holding capacity of the beef sausage was measured by following Honikel and Hamm method (Suparno, 2005). As much as $0.3 \mathrm{~g}$ beef sausage was placed on Whatman filter paper no. 42 and then pressed between glass plates. The pressed sample on Whatman filter paper was then copied to the graph paper so that the produced wet area and pressed meat area could be measured. The WHC was then calculated as follow:

$$
\operatorname{mg~} \mathrm{H}_{2} \mathrm{O}(\mathrm{X})=\underset{8.0}{\text { wet }} \text { area }\left(\mathrm{cm}^{2}\right) / 0.0948-
$$

$\%$ wet area $\quad=X /$ sample weight $\times 100 \%$

$\% \mathrm{WHC} \quad=\%$ sample moisture $-\%$ wet area

\section{Texture}

The sausage texture was measured by using tensile strength texture analyzer (Stable Micro Systems). The hardness test was done by using initial speed (pre-speed) at $1.0 \mathrm{~mm} / \mathrm{s}$, reading speed (test) at $1.0 \mathrm{~mm} / \mathrm{s}$ and final speed at (post-test) $10.0 \mathrm{~mm} / \mathrm{s}$, with pressing distance at $25 \%$ from the initial length by using $\mathrm{P} / 35$ probe cylinder for 60 (Schmiele et al., 2015).

\section{Proximate and fiber analysis}

The proximate analysis includes moisture, protein, fat and ash content analysis by following AOAC (2005), while the fiber content analysis was done by following Sudarmadji et al. (1984). The dietary fiber content was measured by using multienzyme method, where sample was initially dried and grinded into powder before analysis. The sample was the freeze dried and stored. The dietary fiber analysis includes insoluble dietary fiber and soluble dietary fiber (Asp et al., 1983).

\section{Amino acids}

The amino acids content was analyzed by using High Performance Liquid Chromatography as following Macrae (1990).

\section{Microstructure}

The sausage microstructure was observed by using scanning electron microscope (SEM, TM3000, Hitachi HighTechnologies Corp., Tokyo, Japan). The sausage was cut at 1 to $2 \mathrm{~mm}$ thickness, and then fixed with $2.5 \%$ glutaraldehyde on $0.2 \mathrm{M}$ phosphate buffer $(\mathrm{pH} 7)$ for $2 \mathrm{~h}$, washed, soaked and then distilled for $1 \mathrm{~h}$. The sample was then hydrated by using $50 \%, 60 \%, 70 \%, 80 \%, 90 \%$ and $100 \%$ ethanol for an h each. The sample was then placed on the holder,coated with gold, and then visualized by using the scanning electron microscope (Hashemi and Jafarpour, 2016). 


\section{Organoleptic test}

The descriptive organoleptic test was done to understand the sensory properties of the beef sausage. The test was done by using method of single stimuli with sausage texture, aroma, and flavor as the measured variables. Each variable was scored from 1 to 5, with 1 indicates lowest sensory quality and 5 indicates the highest sensory quality (Lawless and Heymann, 1998).

\section{Data analysis}

All of the data were analysed by using two-way analysis of variance, and followed with Duncan's test to determine significance at $\mathrm{P} \leq 0.05$.

\section{RESULTS AND DISCUSSIONS}

\section{Physical properties}

The analysis of variance to the physical properties of beef sausage with different elephant foot yam flour and soybean oil addition did not show any significant difference on $\mathrm{pH}$ between all treatments (Table 1). The $\mathrm{pH}$ of beef protein which highly determine the sausage $\mathrm{pH}$ in this research was around 6 , which as according to Huff-Lonergan and Lonergan (2005) would have high water binding capacity, thus would initiate preferable protein-water-carbohydrate interaction. The addition of elephant foot yam flour and soybean oil in this study showed no effect on the $\mathrm{pH}$ of beef sausage, thus indicate its potential to be used for beef sausage production as both ingredients did not alter the sausage $\mathrm{pH}$ and did not affect the protein-water-carbohydrate interaction.

The water holding capacity of beef sausage in this study showed highly significant difference $(\mathrm{P} \leq 0.01)$ between different addition levels of elephant foot yam flour and soybean oil. The higher concentration of elephant foot yam flour showed higher WHC of beef sausage as well. The result is caused by the starch and dietary fiber content in the flour which had the emulsifying and gelation properties (Lorenzo et al., 2016).

Table 1. Physical properties of beef sausage with different elephant foot yam flour (EFYF) and soybean oil (SBO) addition

\begin{tabular}{ccccccc}
\hline Treatments & $\mathrm{pH}$ & WHC $(\%)$ & Texture $(\mathrm{N})$ & Color L & Color a* & Color $\mathrm{b}^{*}$ \\
\hline EFYF $(\%)$ & & & & & & \\
10 & $6.38 \pm 0.32$ & $54.42 \pm 4.86_{\mathrm{a}}$ & $27.99 \pm 1.41_{\mathrm{a}}$ & $46.08 \pm 2.18$ & $15.60 \pm 0.40_{\mathrm{c}}$ & $16.41 \pm 1.83$ \\
15 & $5.71 \pm 0.39$ & $59.09 \pm 1.16_{\mathrm{b}}$ & $30.43 \pm 0.97_{\mathrm{b}}$ & $45.39 \pm 1.88$ & $14.41 \pm 0.46_{\mathrm{a}}$ & $16.22 \pm 1.37$ \\
20 & $6.39 \pm 0.36$ & $64.81 \pm 1.39_{\mathrm{c}}$ & $39.43 \pm 4.58_{\mathrm{c}}$ & $45.41 \pm 2.06$ & $14.50 \pm 0.17_{\mathrm{a}}$ & $16.36 \pm 1.64$ \\
SBO $(\%)$ & & & & & & \\
10 & $6.41 \pm 2.50$ & $60.43 \pm 2.27_{\mathrm{c}}$ & $31.42 \pm 1.56_{\mathrm{a}}$ & $45.93 \pm 1.70$ & $15.04 \pm 1.73$ & $16.39 \pm 1.38$ \\
15 & $6.45 \pm 2.52$ & $59.50 \pm 4.43_{\mathrm{b}}$ & $32.39 \pm 1.46_{\mathrm{ab}}$ & $45.74 \pm 2.92$ & $14.88 \pm 2.03$ & $16.06 \pm 1.38$ \\
20 & $5.62 \pm 2.49$ & $58.39 \pm 3.44_{\mathrm{a}}$ & $34.03 \pm 1.99_{\mathrm{c}}$ & $45.20 \pm 2.86$ & $14.59 \pm 2.06$ & $16.54 \pm 1.42$ \\
\hline
\end{tabular}

Description: Different superscripts on the same column indicate highly significant differences $(\mathrm{P} \leq 0.01)$ on $\mathrm{WHC}$ and texture, and significant differences $(\mathrm{P} \leq 0.05)$ on color $\mathrm{a}^{*}$ with the addition of elephant foot yam flour.

Different superscripts on the same column indicate significant differences $(\mathrm{P} \leq 0.05)$ on WHC and texture with the addition of soybean oil.

The increased WHC of the beef sausage is also followed by its hardness texture, which would determine the sausage firmness or chewiness. The addition of fat compounds in meat would stabilize protein emulsion and produce smoother surface, even though the addition would also decrease the water holding capacity. However, the addition of soybean oil in this research did not show significant decrease in the WHC. Jamilah et al. (2009) explained that up to $30 \%$ starch addition would increase tensile strength, deformation and gel strength of fish meat, and in addition, 
would increase the water absorption as well. The addition of elephant foot yam flour and soybean oil on beef sausage showed a highly significant interactions $(\mathrm{P} \leq 0.01)$ to the sausage hardness texture and WHC (Table 2).

This showed that the elephant foot yam flour could be used as filling and binding agent which incorporate with soybean oil to form a good protein emulsion.
The higher of elephant foot yam flour addition and soybean oil showed significant rheological change due to the starch gelation. The electrostatic interaction of protein and starch would form stable dispersion within the sausage (Jamila et al., 2009). Zhang et al. (2016) also described that konjac glucomannan had water absorbing, gelation, and emulsifying properties.

Table 2. Interaction of different elephant foot yam flour (EFYF) and soybean oil (SBO) addition to the physical properties of beef sausage

\begin{tabular}{llll}
\hline Treatments & Texture $(\mathrm{N})$ & Color L & WHC \\
\hline EFYF 10\% SBO 10\% & $28.49_{\mathrm{a}}$ & $45.57_{\mathrm{ab}}$ & $56.18_{\mathrm{c}}$ \\
EFYF 10\% SBO 15\% & $27.94 \mathrm{a}$ & $46.10_{\mathrm{ab}}$ & $54.10 \mathrm{~b}$ \\
EFYF 10\% SBO 20\% & $27.56_{\mathrm{a}}$ & $46.20_{\mathrm{b}}$ & $52.98 \mathrm{a}$ \\
EFYF 15\% SBO 105 & $27.30_{\mathrm{a}}$ & $45.50_{\mathrm{a}}$ & $59.91 \mathrm{e}$ \\
EFYF 15\% SBO 15\% & $30.06_{\mathrm{a}}$ & $45.37_{\mathrm{a}}$ & $59.14_{\mathrm{e}}$ \\
EFYF 15\% SBO 20\% & $33.93_{\mathrm{b}}$ & $45.17_{\mathrm{a}}$ & $58.22_{\mathrm{d}}$ \\
EFYF 20\% SBO 10\% & $38.48 \mathrm{c}$ & $45.07_{\mathrm{a}}$ & $65.19 \mathrm{~g}$ \\
EFYF 20\% SBO 15\% & $39.19_{\mathrm{c}}$ & $44.97 \mathrm{a}$ & $65.27 \mathrm{~g}$ \\
EFYF 20\% SBO 20\% & $40.61_{\mathrm{c}}$ & $44.70_{\mathrm{a}}$ & $63.96_{\mathrm{f}}$ \\
\hline
\end{tabular}

Description: Different superscripts on the same column indicate highly significant differences $(\mathrm{P} \leq 0.01)$ on the texture and WHC, and significant differences $(\mathrm{P} \leq 0.05)$ on $\mathrm{L}$ color.

The sausage brightness (L color) was not significantly different (Table 1) between each treatment. This showed that the different addition levels of elephant foot yam flour and soybean oil produced relatively similar sausage color, both for $\mathrm{L}$, $a^{*}$, and $b^{*}$ color. However, higher elephant foot yam flour addition tends to produce lower sausage brightness (L), while different soybean oil addition showed no observed effect on the sausage color.

In table 2, it can be seen that the interaction between elephant foot yam flour and soybean oil addition, with higher flour addition (20\%) showed higher texture at all soybean oil concentrations in this research. This showed that the soybean oil hand an important role to maintain the protein emulsion stability to bind protein molecules (Mejia et al., 2018). The polysaccharides contained in elephant foot yam flour are starch and foot fiber. Kim et al. (2019) stated that konjac flour contained glucomannan which would increase viscosity, gel strength, and chewy texture of the sausage. Thus, the combination of starch, carrageenan, and gum could be used as fat analog for low-fat meat products (JimenezColmenero et al. 2013). The soybean oil addition at up to $20 \%$ would reduce the WHC of the food product, however, the sausage WHC in this research remained stable due to the addition of elephant foot yam flour which has water absorption properties.

In this research, at $20 \%$ elephant foot yam flour and $20 \%$ soybean oil addition showed syneresis with the highest gel strength. Mejia et al. (2018) described that dispersed phase fat compounds on the protein-water solution would form emulsion like three-dimensional matrix as seen during microstructure observation (Figure 1). The microstructure observation of beef sausage 
with different elephant foot yam flour and soybean oil addition is presented in Figure 1. The A1, A2, and A3 in figure 1 showed the microstructure of beef sausage with $10 \%$ elephant foot yam flour addition and different soybean oil addition (10\%, 15\%, and $20 \%$, respectively). The B1, B2, and B3 in figure 1 showed the microstructure of beef sausage with $15 \%$ elephant foot yam flour addition and different soybean oil addition, while $\mathrm{C} 1, \mathrm{C} 2$, and $\mathrm{C} 3$ in figure 1 showed the microstructure of beef sausage with $20 \%$ elephant foot yam flour addition and different soybean oil addition. The microstructure observation showed that the addition of elephant foot yam flour addition gave strong and firm gel protein, as seen in $\mathrm{A} 1, \mathrm{~B} 1$, and $\mathrm{C} 1$. This indicates that $10 \%$ soybean oil addition could not dissolve all of the starch in the sausage mixture, as starch granules were not well dispersed, and form gel matrix due to the moisture deficiency. Different results were shown on $15 \%$ and $20 \%$ soybean oil addition, which had welldispersed starch granule and pores throughout the beef sausage.
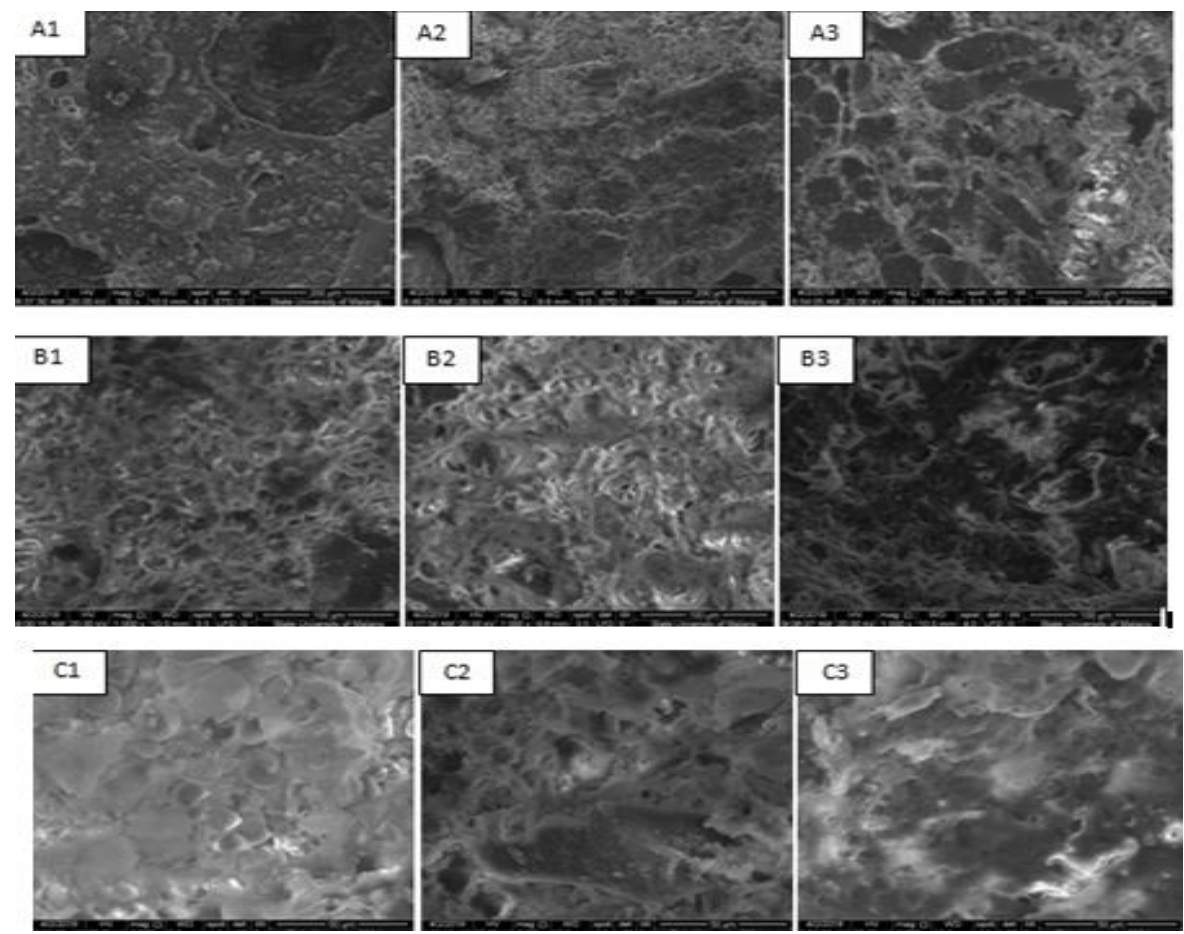

Figure 1. Microstructure of the beef sausage with different elephant foot yam flour (S) and soybean oil (L) additions. A1 (S10L10), A2 (S10L15), A3 (S10L20), B1 (S15L10), B2 (S15L15), B3 (S15L20), C1 (S20L10), C2 (S20 L15) and C3 (S20L20).

\section{Proximate and dietary fiber}

The moisture of beef sausage added with different levels of elephant foot yam flour and soybean oil is presented on Table 3. The results showed that higher elephant foot yam flour addition leads to higher moisture as well. The obtained results were correlated to the $\mathrm{pH}$ and $\mathrm{WHC}$ of the beef sausage. The added water was maintained by the flour and bound along with protein in the three-dimensional matrix system. However, higher soybean oil addition had negative effect to the sausage moisture, even though the addition of soybean oil as much as $20 \%$ showed beef sausage moisture at $66.42 \%$ and is still in accordance to the Indonesian standard for sausage product. According to Arildsen et al. (2014), the addition of fat compounds to the meat products could increase its overall palatability even though would change the products' texture into more porous and often caused syneresis, as happened with $20 \%$ soybean addition in this research. The addition of elephant foot yam flour showed highly significant differences $(\mathrm{P} \leq 0.01)$ to 
the protein content of beef sausage, with $20 \%$ flour addition showed the highest protein content. The results were due to the protein content of elephant foot yam flour $(7.02 \%)$, thus higher flour addition would result in the higher protein content of beef sausage as well.

The protein content measurement is important as it would affect the formed gel strength, which when partially denatured, would be followed with irreversible threedimensional matrix formation (Choi et al., 2011). Moreover, the results showed that the soybean oil addition did not give significant difference to the protein content $(\mathrm{P}>0.05)$. The addition of elephant foot yam flour showed significant effect $(\mathrm{P} \leq 0.05)$ to the fat content of beef sausage, with the highest fat content $(9.46 \%)$ was found on $20 \%$ flour addition. The elephant foot yam flour in this research had $0.62 \%$ fat content, thus even though relatively small would affect the total fat content of the beef sausage. Furthermore, the elephant foot yam flour is high of polysaccharides, whether in the form of dietary fiber or crude fiber.

Table 3. Proximate and crude fiber analysis of beef sausage with different elephant foot yam flour (EFYF) and soybean oil (SBO) addition

\begin{tabular}{cccccc}
\hline Treatments & Moisture (\%) & Protein $(\%)$ & Fat $(\%)$ & Ash $(\%)$ & Crude Fiber $(\%)$ \\
\hline EFYF $(\%)$ & & & & & \\
10 & $67.39 \pm 8.18_{\mathrm{a}}$ & $10.67 \pm 0.40_{\mathrm{a}}$ & $9.06 \pm 8.95_{\mathrm{a}}$ & $1.09 \pm 0.06_{\mathrm{a}}$ & $0.91 \pm 0.12_{\mathrm{a}}$ \\
15 & $68.82 \pm 6.04_{\mathrm{ab}}$ & $10.86 \pm 0.67_{\mathrm{a}}$ & $9.38 \pm 7.85_{\mathrm{b}}$ & $1.24 \pm 0.18_{\mathrm{b}}$ & $1.07 \pm 0.26_{\mathrm{b}}$ \\
20 & $69.63 \pm 5.81_{\mathrm{b}}$ & $11.04 \pm 0.82_{\mathrm{ab}}$ & $9.46 \pm 7.80_{\mathrm{c}}$ & $1.42 \pm 0.36_{\mathrm{c}}$ & $2.91 \pm 0.19_{\mathrm{c}}$ \\
SBO $(\%)$ & & & & & \\
10 & $70.62 \pm 5.72_{\mathrm{b}}$ & $10.92 \pm 0.65$ & $6.74 \pm 7.19_{\mathrm{a}}$ & $1.24 \pm 0.36$ & $1.63 \pm 2.22$ \\
15 & $68.79 \pm 4.01_{\mathrm{b}}$ & $10.85 \pm 0.64$ & $9.14 \pm 6.16_{\mathrm{b}}$ & $1.25 \pm 0.38$ & $1.61 \pm 2.81$ \\
20 & $66.42 \pm 5.25_{\mathrm{a}}$ & $10.80 \pm 0.63$ & $12.02 \pm 6.78_{\mathrm{c}}$ & $1.26 \pm 0.43$ & $1.65 \pm 3.00$ \\
\hline
\end{tabular}

Description: Different superscripts on the same column indicate highly significant differences $(\mathrm{P} \leq 0.01)$ on the moisture and fat content of beef sausage with different SBO addition.

Different superscripts on the same column indicate highly significant differences $(\mathrm{P} \leq 0.01)$ on the ash, protein, and crude fiber content of beef sausage with different EFYF addition.

Different superscript on the same column indicate significant differences $(\mathrm{P} \leq 0.05)$ on the moisture content of beef sausage with EFYF addition.

Table 4. Interaction of elephant foot yam flour (EFYF) and soybean oil (SBO) addition to the fat and crude fiber content of beef sausage

\begin{tabular}{cccc}
\hline \multicolumn{2}{c}{ Fat content interaction (\%) } & \multicolumn{2}{c}{ Crude fiber interaction (\%) } \\
\hline Treatments $(\%)$ & Mean & Treatments $(\%)$ & Mean \\
\hline EFYF 10 SBO 10 & $6.12_{\mathrm{a}}$ & EFYF 10 SBO 15 & $0.86_{\mathrm{a}}$ \\
EFYF 15 SBO 10 & $6.89 \mathrm{~b}$ & EFYF 10 SBO 10 & $0.92 \mathrm{~b}$ \\
EFYF 20 SBO 10 & $7.19_{\mathrm{b}}$ & EFYF 10 SBO 20 & $0.94 \mathrm{~b}$ \\
EFYF 10 SBO 15 & $8.96_{\mathrm{c}}$ & EFYF 15 SBO 10 & $1.04 \mathrm{c}$ \\
EFYF 20 SBO 15 & $9.20_{\mathrm{c}}$ & EFYF 15 SBO 15 & $1.06_{\mathrm{cd}}$ \\
EFYF 15 SBO 15 & $9.27_{\mathrm{c}}$ & EFYF 15 SBO 20 & $1.11_{\mathrm{d}}$ \\
EFYF 15 SBO 20 & $11.98_{\mathrm{d}}$ & EFYF 20 SBO 20 & $2.89 \mathrm{e}$ \\
EFYF 20 SBO 20 & $11.98_{\mathrm{d}}$ & EFYF 20 SBO 15 & $2.91 \mathrm{e}$ \\
EFYF 10 SBO 20 & $12.09_{\mathrm{d}}$ & EFYF 20 SBO 10 & $2.93_{\mathrm{e}}$ \\
\hline
\end{tabular}

Description: Different superscripts indicate significant differences $(\mathrm{P} \leq 0.05)$ on the fat and crude fiber content of beef sausage 
Table 5. Soluble dietary, insoluble dietary, and dietary fiber content of beef sausage with different elephant foot yam flour (EFYF) addition

\begin{tabular}{ccccc}
\hline Treatments & Moisture (\%) & SDF (\%) & IDF (\%) & Total DF (\%) \\
\hline EFYF 10\% & 6.63 & 2.12 & 16.19 & 18.30 \\
EFYF 15\% & 6.85 & 2.22 & 16.77 & 18.98 \\
EFYF 20\% & 7.32 & 2.71 & 17.21 & 19.92 \\
\hline
\end{tabular}

Description: Soluble dietary fiber, IDF: Insoluble dietary fiber, DF: Dietary fiber.

Table 6. Amino acids content of beef sausage added with different elephant foot yam flour (EFYF) addition

\begin{tabular}{lcccc}
\hline \multirow{2}{*}{ Amino acids (\%) } & \multirow{2}{*}{ Beef } & \multicolumn{3}{c}{ Sausage } \\
\cline { 3 - 5 } & & EFYF 10\% & EFYF 15\% & EFYF 20\% \\
\hline Aspartate & 1.39 & 1.02 & 1.07 & 0.95 \\
Serine & 0.75 & 0.39 & 0.33 & 0.32 \\
Glutamate & 2.87 & 2.06 & 2.62 & 1.88 \\
Glycine & 1.30 & 0.85 & 0.85 & 0.77 \\
Histidine & 0.72 & 0.47 & 0.35 & 0.38 \\
Arginine & 1.32 & 1.19 & 1.04 & 1.03 \\
Threonine & 1.21 & 1.08 & 0.90 & 0.93 \\
Alanine & 1.01 & 0.64 & 0.65 & 0.59 \\
Proline & 0.29 & 0.12 & 0.13 & 0.12 \\
Cystine & 0.90 & 0.54 & 0.61 & 0.37 \\
Tyrosine & 0.86 & 0.45 & 0.36 & 0.44 \\
Valine & 1.08 & 1.02 & 0.95 & 0.92 \\
Methionine & 0.74 & 0.34 & 0.28 & 0.31 \\
Lysine & 1.76 & 1.23 & 1.31 & 1.15 \\
Isoleucine & 0.99 & 0.91 & 0.82 & 0.80 \\
Leucine & 1.71 & 1.51 & 1.39 & 1.34 \\
Phenylalanine & 1.37 & 0.90 & 0.72 & 0.76 \\
\hline
\end{tabular}

The addition of the flour would then increase the fiber content of the beef sausage. The flour addition would also increase the ash content of the beef sausage as elephant foot yam flour also had high ash content (10.86\%). Andriansyah (2014) mentioned that fiber rich food would have higher digestibility. Qi et al. (2015) added that crude fiber is undissolved carbohydrate even when heated and solved with sulfuric acid and $\mathrm{NaOH}$ solution. Ash content analysis could then be done to determine the fiber content by subtracting the residual component after burned with the ash content (Septiani et al., 2015). The Duncan's test (Table 4) showed that the addition of elephant foot yam flour and soybean oil were interacted to affect the fat and crude fiber content of the beef sausage, yet the increased fat content were mostly affected by the added soybean oil levels. The similar results were also found with elephant foot yam flour and crude fiber content of the beef sausage.

In Table 5, it can be seen that $20 \%$ elephant foot yam flour addition had the higher dietary fiber (19.83\% to $19.99 \%$ ), thus showed the potetial of the flour utilization as functional food for human health.

\section{Amino acid}

Amino acids are the building blocks for protein, while the protein would determine the structure and texture of the produced beef sausage. The addition of elephant foot yam flour at $10 \%, 15 \%$, and $20 \%$ with $10 \%$ soybean oil showed 17 
detected amino acids in the sausage (Table 17), with valine, tryptophan, and glutamine were not found.

Aside from the elephant foot yam flour addition, other known factors which affect amino acids content were $\mathrm{pH}$ and temperature during processing. In this research, the temperature for sausage processing was at $80^{\circ} \mathrm{C}$ for $20 \mathrm{~min}$. Several heat susceptible amino acids would be then denatured and loss. The highest amino acids in the produced beef sausage were myofibril amino acids, such as glutamic acid, lysine, and leucine, while lysine is the most susceptible to the heat and showed higher decrease. The amino acid profile of the produced beef sausage with $10-11 \%$ protein content in this research are categorized as good quality meat products according to the Indonesian Standard Agency (BSN, 2015).

Table 7. Descriptive sensory analysis of beef sausage with different elephant foot yam flour (EFYF) and soybean oil (SBO) addition

\begin{tabular}{cccc}
\hline Treatments & Texture & Aroma & Flavor \\
\hline EFYF & & & \\
10 & $3.56 \mathrm{a}$ & $3.71_{\mathrm{a}}$ & $3.64 \mathrm{a}$ \\
15 & $4.11_{\mathrm{b}}$ & $4.27 \mathrm{~b}$ & $4.13_{\mathrm{b}}$ \\
20 & $3.64 \mathrm{a}$ & $3.56 \mathrm{a}$ & $3.51_{\mathrm{a}}$ \\
SBO & & & \\
10 & $3.71 \mathrm{a}$ & $3.84 \mathrm{a}$ & $3.80 \mathrm{ab}$ \\
15 & $3.98 \mathrm{~b}$ & $3.89 \mathrm{a}$ & $3.91 \mathrm{~b}$ \\
20 & $3.62 \mathrm{a}$ & $3.80 \mathrm{a}$ & $3.58 \mathrm{a}$ \\
\hline
\end{tabular}

Description: Different superscripts on EFYF addition indicate highly significant differences $(\mathrm{P} \leq 0.01)$ on texture, aroma and flavor of the beef sausage Different superscripts on SBO addition indicate significant differences $(\mathrm{P} \leq 0.05)$ on texture and flavor, but not on aroma of the beef sausage

Table 8. Interaction of elephant foot yam flour (EFYF) and soybean oil (SBO) addition to the sensory properties of beef sausage

\begin{tabular}{lccc}
\hline Treatments & Texture & Aroma & Flavor \\
\hline EFYF 10 SBO10 & $3.30 \mathrm{ab}$ & $3.47 \mathrm{ab}$ & $3.53 \mathrm{ab}$ \\
EFYF 10 SBO 15 & $3.60 \mathrm{abc}$ & $3.60 \mathrm{abc}$ & $3.67 \mathrm{ab}$ \\
EFYF 10 SBO 20 & $3.73 \mathrm{bc}$ & $4.007 \mathrm{cde}$ & $3.73 \mathrm{bc}$ \\
EFYF 15 SBO 10 & $3.93_{\mathrm{c}}$ & $4.20 \mathrm{de}$ & $4.13_{\mathrm{cd}}$ \\
EFYF 15 SBO 15 & $4.47 \mathrm{~d}$ & $4.53 \mathrm{e}$ & $4.53 \mathrm{~d}$ \\
EFYF 15 SBO 20 & $3.93_{\mathrm{c}}$ & $4.07 \mathrm{cde}$ & $3.73 \mathrm{bc}$ \\
EFYF 20 SBO 10 & $3.87 \mathrm{c}$ & $3.87 \mathrm{bcd}$ & $3.73 \mathrm{bc}$ \\
EFYF 20 SBO 15 & $3.87 \mathrm{c}$ & $3.53 \mathrm{ab}$ & $3.73 \mathrm{bc}$ \\
EFYF 20 SBO 20 & $3.20 \mathrm{a}$ & $3.27 \mathrm{a}$ & $3.27 \mathrm{a}$ \\
\hline
\end{tabular}

Description: Different superscripts indicate significant difference $(\mathrm{P} \leq 0.05)$ on the EFYF and SBO addition to the sensory properties of beef sausag

\section{Sensory properties}

In this research, the sensory properties (texture, aroma, and flavor) of the produced beef sausage were measured through organoleptic test. The obtained score for beef texture in this research were ranged from 3.5 to 4.1 , with the highest score were obtained with $15 \%$ elephant foot yam flour and $15 \%$ soybean oil addition, which are categorized as chewy and acceptable. The addition of elephant foot yam flour showed significant effect $(\mathrm{P} \leq 0.05)$ on the aroma of beef sausage, with the obtained score were ranged from 3.5 (balanced flour and beef aroma) to 4.2 (had beef aroma), and overall score were accepted by the panelists. 
The results indicate that the flour could be used as filling and binding agent for beef sausage as the addition could produce good texture and did not significantly change the beef aroma. The addition of soybean oil also did not affect the aroma of beef sausage, with the average aroma score was 3.8. Furthermore, the addition of elephant foot yam flour and soybean oil showed significant effect $(\mathrm{P} \leq 0.05)$ to the flavor of the beef sausage, with the average score were ranged from 3.5 (balanced beef and flour flavor) to 4.2 (beefy flavor). The highest flavor score of beef sausage in this research was obtained by the $15 \%$ elephant foot yam and $15 \%$ soybean oil addition.

In Table 8 , it can be seen that there was significant interaction $(\mathrm{P} \leq 0.05)$ of elephant foot yam flour and soybean oil to the texture, aroma and flavor of the produced beef sausage. The most preferred beef sausage texture, aroma and flavor was obtained by the $15 \%$ elephant foot yam flour and $15 \%$ soybean oil addition. This showed that the addition of both ingredients at $15 \%$ concentration was able to maintain the preferred texture and prevent syneresis. Jimenez-Colmenero et al. (2010) stated that meat processed products should be made from fresh ingredients as it correlates with the water binding capacity on gel matrix. Other factors that should be noted are the added seasoning, fat or other hydrocolloids as the additions would affect the consumers' acceptability.

\section{CONCLUSION}

The research concludes that the addition of elephant foot yam flour and soybean oil addition affect the physicochemical properties of the beef sausage. The higher elephant foot yam flour and soybean oil addition showed better physical properties of the beef sausage, yet would be less preferred by the consumer.

\section{ACKNOWLEDGMENTS}

The authors would like to thank the Directorate General of Higher Education, Ministry of Education and Culture of Indonesia for the research funding through Postgraduate Scholarship.

\section{REFERENCES}

Abdolghafour, B., \& Saghir, A. (2014). Development in sausage production and practices-A review Sausage Production: Ingredients and Raw. Journal of Meat Science and Technology, 2(3), 40-50.

Amin, M. . (2014). Sukses Bertani Buncis. In Sayuran Obat Kaya Manfaat. Yogyakarta: Garudhawaca.

Arildsen Jakobsen, L. M., Vuholm, S., Aaslyng, M. D., Kristensen, M., Sørensen, K. V., Raben, A., \& Kehlet, U. (2014). Sensory characteristics and consumer liking of sausages with $10 \%$ fat and added rye or wheat bran. Food Science \& Nutrition, 2(5), 534-546. https://doi.org/10.1002/fsn3.126

Asp, N. G., Johansson, C. G., Hallmer, H., \& Siljestroem, M. (1983). Rapid enzymic assay of insoluble and soluble dietary fiber. Journal of Agricultural and Food Chemistry, 31(3), 476-482. https://doi.org/10.10 21/jf00117a003

Badan Standardisasi Nasional. (2008). Lunak. In Kembang gula (2nd ed.). Jakarta: Badan Standardisasi Nasional.

Choi, Y.-S., Choi, J.-H., Han, D.-J., Kim, H.-Y., Lee, M.-A., Kim, H.-W., Kim, C.-J. (2011). Effects of rice bran fiber 
on heat-induced gel prepared with pork salt-soluble meat proteins in model system. Meat Science, 88(1), 59-66. https://doi.org/10.1016/j.meat sci.2010.12.003

Faridah, D. N. (2005). Sifat fisiko kimia tepung suweg (Amorphophallus campanulatus B1.) dan indeks glisemiknya. Teknologi Dan Industri Pangan, 16(3), 254-259.

Hashemi, A., \& Jafarpour, A. (2016). Rheological and microstructural properties of beef sausage batter formulated with fish fillet mince. Journal of Food Science and Technology, 53(1), 601-610. https:// doi.org/10.1007/s13197-015-2052-4

Huff-Lonergan, E., \& Lonergan, S. M. (2005). Mechanisms of water-holding capacity of meat: The role of postmortem biochemical and structural changes. Meat Science, 71(1), 194-204. https://doi.org/10.10 16/j.meatsci.2005.04.022

Hutching, J. B. (2003). Food Colour and Appearance (2nd ed.). Gaithersburg: Aspen Publication, Inc.

Isa, I. (2011). Penetapan asam lemak linoleat dan linolenat pada minyak kedelai secara kromatografi gas. Saintek, 6(1980), 1-6.

Jamilah, B., Mohamed, A., Abbas, K. A., Abdul Rahman, R., Karim, R., \& Hashim, D. M. (2009). Protein-starch interaction and their effect on thermal and rheological characteristics of a food system: A review. Journal of Food, Agriculture and Environment, 7(2), 169-174.

Jimenez-Colmenero, F., Cofrades, S., Herrero, A. M., Solas, M. T., \& RuizCapillas, C. (2013). Konjac gel for use as potential fat analogue for healthier meat product development: Effect of chilled and frozen storage. Food Hydrocolloids, 30(1), 351-357. https:// doi.org/10.1016/j.foodhyd.2012.06.015

Jiménez-Colmenero, F., Cofrades, S., López-López, I., Ruiz-Capillas, C., Pintado, T., \& Solas, M. T. (2010). Technological and sensory characteristics of reduced/low-fat, low-salt frankfurters as affected by the addition of konjac and seaweed. Meat Science, 84(3), 356-363. https://doi. org/10.1016/j.meatsci.2009.09.002

Kim, D. H., Shin, D. M., Seo, H. G., \& Han, S. G. (2019). Effects of konjac gel with vegetable powders as fat replacers in frankfurter-type sausage. Asian-Australasian Journal of Animal Sciences, 32(8), 1195-1204. https:// doi.org/10.5713/ajas.18.0781

Lorenzo, J. M., Munekata, P. E. S., Pateiro, M., Campagnol, P. C. B., \& Domínguez, R. (2016). Healthy Spanish salchichón enriched with encapsulated $n-3$ long chain fatty acids in konjac glucomannan matrix. Food Research International, 89, 289-295. https://doi.org/10.1016/j.fo odres.2016.08.012

Qi, J., Yokoyama, W., Masamba, K. G., Majeed, H., Zhong, F., \& Li, Y. (2015). Structural and physicochemical properties of insoluble rice bran fiber: effect of acid-base induced modifications. RSC Advances, 5(97), 79915-79923. https://doi.org/10.1039 /C5RA15408A

Schmiele, M., Nucci Mascarenhas, M. C. C., da Silva Barretto, A. C., \& Rodrigues Pollonio, M. A. (2015). Dietary fiber as fat substitute in emulsified and cooked meat model system. LWT Food Science and Technology, 61(1), 105-111. https://doi.org/10.1016/j.lwt .2014 .11 .037 
Septiani, D., Hendrawan, Y., \& Yulianigsih, R. (2015). Uji karakteristik fisik, kimia dan organoleptik pembuatan pangan alternatif. Jurnal Bioproses Komoditas Tropis, 3(1).

Vasquez Mejia, S. M., de Francisco, A., Manique Barreto, P. L., Damian, C., Zibetti, A. W., Mahecha, H. S., \& Bohrer, B. M. (2018). Incorporation of $\beta$-glucans in meat emulsions through an optimal mixture modeling systems. Meat Science, 143, 210-218. https:// doi.org/10.1016/j.meatsci.2018.05.007

Zhang, Z.-H., Peng, H., Woo, M. W., Zeng, X.-A., Brennan, M., \& Brennan, C. S. (2020). Preparation and characterization of whey protein isolate-chlorophyll microcapsules by spray drying: Effect of WPI ratios on the physicochemical and antioxidant properties. Journal of Food Engineering, 267, 109729. https://doi. org/10.1016/j.jfoodeng.2019.109729 